\title{
PEMATANGAN GONAD INDUK ABALON Haliotis squamata MELALUI PENGELOLAAN PAKAN
}

\author{
Ibnu Rusdi, Riani Rahmawati, Bambang Susanto, dan I Nyoman Adiasmara Giri \\ Balai Besar Riset Perikanan Budidaya Laut \\ Jl. Br. Gondol, Kec. Gerokgak, Kab. Buleleng-Kotak Pos 140, Singaraja, Bali 81101 \\ E-mail: ibnurusdi09@yahoo.com
}

(Naskah diterima: 22 Juni 2010; Disetujui publikasi: 4 November 2010)

\begin{abstract}
ABSTRAK
Abalon merupakan hewan yang bersifat herbivora di alam memakan berbagai jenis makroalga. Penelitian ini bertujuan untuk mengetahui pengaruh berbagai makroalga sebagai pakan terhadap perkembangan gonad abalon Haliotis squamata. Dalam penelitian ini diterapkan 4 perlakuan pemberian pakan yaitu: (A) Gracilaria sp., (B) Ulva sp., (C) Sargassum sp., (D) Kombinasi Gracilaria sp. + Ulva sp. + Sargassum sp. (rasio 1:1:1). Rancangan yang digunakan adalah rancangan acak lengkap masing-masing dengan 3 ulangan. Induk-induk abalon dipelihara dalam 12 buah kontainer plastik berlubang ukuran $0,58 \mathrm{~m} \times 0,39 \mathrm{~m} \times 0,31 \mathrm{~m}$ dan ditempatkan dalam sebuah bak semen ukuran $3 \mathrm{~m} \times 2 \mathrm{~m} \times 1 \mathrm{~m}$. Setiap kontainer berisi abalon sebanyak 10 ekor dengan ukuran awal rata-rata panjang cangkang dan bobot masing-masing 58,9 $\pm 1,37 \mathrm{~mm}$ dan $36,1 \pm 4,06 \mathrm{~g}$. Pakan diberikan dengan dosis $15 \%-20 \%$ dari bobot biomassa setiap 2 hari sekali. Pergantian air menggunakan sistem sirkulasi dengan debit 5-6 L/menit. Hasil penelitian menunjukkan bahwa rata-rata pertumbuhan bobot mutlak dan laju pertumbuhan bobot harian berbeda nyata $(P<0,05)$ antar perlakuan. Tingkat kematangan gonad (TKG) induk abalon pada hari ke-70 diperoleh TKG-III tertinggi dihasilkan pada perlakuan kombinasi Gracilaria + Ulva sp. + Sargassum sp. $(\mathrm{P}<0,05)$. Perlakuan pakan kombinasi Gracilaria sp. + Ulva sp. dan Sargassum sp. terlihat lebih sesuai dalam memacu pematangan gonad induk abalon $H$. squamata.
\end{abstract}

KATA KUNCl: Haliotis squamata, Gracilaria, Ulva, Sargassum, perkembangan gonad

ABSTRACT: Gonadal maturation of abalone, Haliotis squamata, broodstock through food management. By: Ibnu Rusdi, Riani Rahmawati, Bambang Susanto, and I Nyoman Adiasmara Giri

Abalone is a herbivorous animal which consumes various kinds of macroalgae in the wild. The aim of the study was to study the effects of various kinds of macroalgae on gonadal maturation of abalone, Haliotis squamata. The experiment applied four kinds of macroalgae i.e.: (A) Gracilaria sp.; (B) Ulva sp.; (C) Sargassum sp.; and (D) Combination of Gracilaria sp. + Ulva sp. + Sargassum sp. (ratio 1:1:1) as food for abalone broodstock. The experiment was arranged in complete random design with three replications. One cemented tank of $3 \mathrm{~m} \times 2 \mathrm{~m} \times 1 \mathrm{~m}$ in size was used for the observation. Twelve plastic containers of $0,58 \mathrm{~m} \times 0,39 \mathrm{~m} \times 0,31 \mathrm{~m}$ in size were placed in the tank and stocked with 10 abalones per container with the average size of shell length and body weight were $58.9 \pm 1.37 \mathrm{~mm}$ and $36.1 \pm 4.06 \mathrm{~g}$, respectively. For each treatment, macroalgae was given daily with the dosage between $15 \%$ and $20 \%$ from the total of body weight. Water exchange was done using flow-through system with rate of exchange of 5-6 L/minute. The result of the study showed that the average of 
absolute growth and daily growth rate of abalones were significantly different $(P<0.05)$ among treatments. The observation of gonadal development of abalone broodstocks on day-70 revealed that the latest stage III of gonadal maturation was achieved by the broodstock fed with combination treatment of Gracilaria sp. + Ulva sp. + Sargassum sp. $(P<0.05)$. Combination of macroalgae from this treatment was clearly able to stimulate gonadal maturation of $\boldsymbol{H}$. squamata broodstock.

KEYWORDS: Haliotis squamata, Gracilaria, Ulva, Sargassum, gonadal development

\section{PENDAHULUAN}

Abalon (Haliotis spp.) tergolong ke dalam klas Gastropoda, famili Haliotidae, dan merupakan salah satu jenis moluska laut yang memiliki nilai eksotik dan ekonomis tinggi karena cangkangnya digunakan sebagai hiasan dan dagingnya sangat digemari sebagai salah satu makanan yang lezat dan bergizi tinggi (McBride \& Conte, 2008). Permintaan dunia terhadap abalon cenderung meningkat sejalan dengan makin meningkatnya pendapatan per kapita penduduk dan kebutuhan terhadap variasi sumber protein. Abalon umumnya dipasarkan ke negara-negara Asia di antaranya Cina, Hong Kong, Korea, Jepang, dan Singapura. Namun, hingga saat ini mayoritas produksi abalon dunia masih didominasi dari hasil tangkapan di alam. Pada tahun 2002 produksi abalon dunia diperkirakan mencapai 22.600 ton, namun hanya lebih kurang 8.600 ton dihasilkan dari kegiatan budidaya (Gordon \& Cook, 2004).

Beberapa negara penghasil abalon budidaya di antaranya Cina, Taiwan, Jepang, Afrika Selatan, Amerika Serikat, Meksiko, Irlandia, Islandia, Australia, dan Selandia Baru (Hahn, 1989; Gordon \& Cook, 2001). Namun hingga saat ini Cina masih menjadi negara penghasil abalon budidaya terbesar di dunia dengan total produksi mencapai 4.500 ton (Gordon \& Cook, 2004). Hingga saat ini Indonesia masih mengandalkan hasil tangkapan abalon dari alam yang produksinya cenderung mengalami penurunan, bahkan di beberapa daerah penangkapan dilaporkan telah terjadi eksploitasi berlebihan. Oleh karena itu, perlu upaya pembenihan dan budidaya untuk mengurangi tekanan penangkapan abalon di alam guna lebih mendukung budidaya abalon secara berkelanjutan.

Pengembangan budidaya abalon saat ini masih terkendala oleh terbatasnya sediaan benih. Oleh karena itu, Balai Besar Riset
Perikanan Budidaya Laut, Gondol telah melakukan penelitian perbenihan abalon, khususnya spesies $H$. squamata (Susanto et al., 2007; Rusdi et al., 2008). Namun salah satu kendala yang masih dihadapi adalah sulitnya memperoleh induk abalon siap pijah dari hasil penangkapan langsung di alam. Setyono (2006) melaporkan kesulitan melakukan pemijahan abalon $H$. asinina dari hasil tangkapan langsung dari alam. Hal yang sama juga dilaporkan pada beberapa spesies abalon di antaranya $H$. midae di Afrika Selatan, $H$. australis di Australia, dan $H$. fulgens, $H$. corrogata, H. cracherodii di California (Hahn, 1989; Moss, 1998; Sales \& Britz, 2001). Induk abalon hasil tangkapan dari alam pada umumnya sulit untuk langsung dipijahkan walaupun melalui metode perangsangan (induce spawning) karena alasan tingkat kematangan gonadnya yang sangat bervariasi. Oleh karena itu, salah satu tahapan kegiatan yang mesti dilakukan dalam perbenihan abalon yaitu melakukan proses pematangan gonad dan penyediaan induk siap pijah secara berkesinambungan di hatcheri.

Berbagai jenis makroalga merupakan makanan yang sangat disukai abalon dewasa di alam. Padua et al. (2004) mengklasifikasikan alga ke dalam tiga kelompok berdasarkan warna, yaitu alga hijau (Chlorophyta), alga coklat (Phaeophyta), dan alga merah (Rhodophyta). Terdapat tiga faktor yang berpengaruh terhadap pemilihan jenis alga bagi abalon di alam, yaitu keberadaan senyawa metabolit kimia yang ada pada alga, morfologi dan nilai nutrisi alga (Shepherd \& Steinberg, 1992). Jenis alga merah Gracilaria sp. pada umumnya dilaporkan baik untuk pertumbuhan maupun pematangan gonad abalon $H$. asinina (Singhagraiwan \& Doi, 1993; Priyambodo et al., 2005; Setyono, 2006; Indarjo et al., 2007). Penelitian guna mengetahui kombinasi jenis pakan alga yang sesuai dalam memacu pertumbuhan dan pematangan gonad abalon 
H. midae telah dilaporkan di Afrika Selatan (Troell et al., 2006), namun untuk abalon $H$. squamata belum diketahui.

Penelitian ini bertujuan untuk mengetahui jenis makroalga yang sesuai dalam memacu pematangan gonad induk abalon $\mathrm{H}$. squamata, sehingga dapat menjadi acuan dan informasi awal bagi pengembangan perbenihan abalon jenis tersebut di hatcheri.

\section{BAHAN DAN METODE}

Penelitian berlangsung di Hatcheri Balai Besar Riset Perikanan Budidaya Laut, GondolBali dari bulan Agustus-Oktober 2009. Biota uji yang digunakan dalam penelitian ini adalah abalon ( $H$. squamata) yang diperoleh dari penangkapan di pantai Pekutatan, Kabupaten Jembrana, Bali dengan ukuran rata-rata panjang cangkang $58,9 \pm 1,37 \mathrm{~mm}$, lebar cangkang $38,0 \pm 0,99 \mathrm{~mm}$, dan bobot $36,1 \pm 4,06 \mathrm{~g}$.

Penelitian dilakukan dalam sebuah bak semen berukuran $3 \mathrm{~m} \times 2 \mathrm{~m} \times 1 \mathrm{~m}$. Induk abalon ditempatkan dan dipelihara dalam unit-unit percobaan menggunakan keranjang plastik berlubang dengan ukuran 0,58 $\mathrm{m} \times 0,39 \mathrm{~m} \times$ 0,31 m sebanyak 12 buah. Setiap keranjang ditambahkan potongan pipa PVC berbentuk setengah lingkaran diameter 4 inci berukuran panjang $45 \mathrm{~cm}$ yang berfungsi sebagai substrat abalon. Setiap keranjang ditebari abalon sebanyak 10 ekor. Biota uji dari masingmasing perlakuan diberi pakan sesuai perlakuan dengan dosis 15\%-20\% dari bobot biomassa setiap 2 hari sekali. Penyesuaian dosis pakan dilakukan setiap kali pengamatan setelah melakukan penimbangan biota uji. Penyiponan untuk membersihkan kotoran dan sisa pakan dilakukan sebelum penggantian dan pemberian pakan berikutnya. Pergantian air menggunakan sistem sirkulasi dengan debit berkisar 5-6 L/menit.

Percobaan dirancang menggunakan pola rancangan acak lengkap dan menerapkan 4 perlakuan masing-masing dengan 3 ulangan. Adapun keempat perlakuan pakan yang diujikan, yaitu pemberian makroalga dari jenis: (A) Gracilaria sp., (B) Ulva sp., dan (C) Sargassum sp., dan (D) Kombinasi Gracilaria sp. + Ulva sp. + Sargassum sp. (rasio 1:1:1). Penempatan unit-unit percobaan dilakukan secara acak mengikuti pola rancangan acak lengkap (Steel \& Torrie, 1993).

Pengukuran biota uji meliputi panjang dan lebar cangkang serta penimbangan bobot badan abalon dilakukan setiap 15 hari. Pengukuran panjang dan lebar cangkang dilakukan menggunakan jangka sorong, sedangkan penimbangan bobot badan abalon menggunakan timbangan digital. Untuk memudahkan pelepasan abalon dari substrat digunakan alat bantu spatula, sebelum dilakukan penimbangan abalon dikeringkan menggunakan kertas penyerap air untuk mengurangi kandungan air di tubuhnya.

Peubah yang diamati meliputi pertumbuhan bobot mutlak abalon mengikuti rumus Effendie (1997), laju pertumbuhan harian menggunakan rumus Zonneveld et al. (1991), pertumbuhan panjang mutlak cangkang menggunakan rumus Cox (1996), sedangkan pengamatan perkembangan gonad dilakukan mengikuti Singhagraiwan \& Doi (1993) sebagai berikut:

$$
\begin{aligned}
\text { - Tingkat } 0= & \text { Gonad belum berkembang } \\
\text { - Tingkat } 1= & \begin{array}{l}
\text { Gonad sedikit menutupi } \\
\text { bagian hepatopankreas }
\end{array} \\
\text { - Tingkat } 2= & \begin{array}{l}
\text { Gonad sekitar } 25 \% \text { menutupi } \\
\text { bagian hepatopankreas }
\end{array} \\
\text { - Tingkat } 3= & \begin{array}{l}
\text { Gonad sekitar } 50 \% \text { menutupi } \\
\text { bagian hepatopankreas }
\end{array}
\end{aligned}
$$

Analisis proksimat rumput laut dilakukan di Laboratorium Nutrisi dan Teknologi Pakan Balai Besar Riset Perikanan Budidaya Laut, Gondol, sedangkan analisis asam lemak makroalga dan daging abalon dilakukan di laboratorium Pusat Studi Pangan dan Gizi, Universitas Gadjahmada.

Data yang diperoleh dianalisis menggunakan sidik ragam dan dilanjutkan dengan uji beda nyata terkecil. Sebagai data penunjang dilakukan pengukuran beberapa parameter fisika-kimia air media penelitian meliputi: suhu, salinitas, pH, oksigen terlarut, nitrit, dan amoniak.

\section{HASIL DAN BAHASAN}

Hasil pengamatan terhadap tingkat perkembangan gonad abalon ( $H$. squamata) yang dilakukan pada masing-masing perlakuan selama 70 hari pemeliharaan disajikan pada Gambar 1. Terlihat bahwa pada umumnya tingkat kematangan gonad (TKG) induk abalon pada awal pemeliharaan berada pada TKG-1 . Memasuki periode pemeliharaan hari ke-28, induk abalon pada umumnya mengalami perkembangan gonad ke TKG-2, walaupun induk yang mencapai TKG-3 sudah mulai 

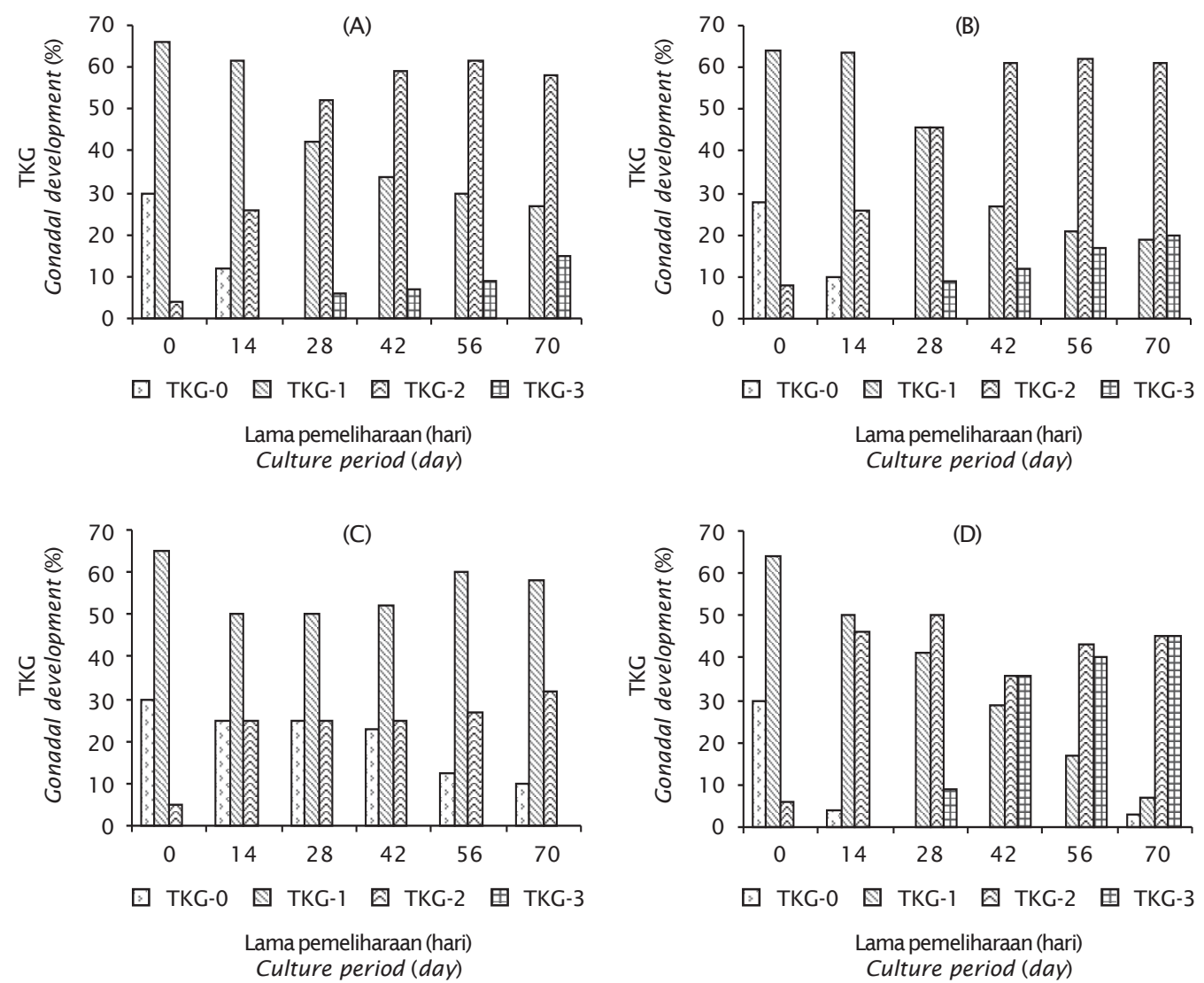

Gambar 1. Rata-rata perkembangan tingkat kematangan gonad (TKG) abalon H. squamata pada masing-masing perlakuan selama 70 hari pemeliharaan ( $\mathrm{A}=$ Gracilaria sp., $\mathrm{B}=$ Ulva sp., $\mathrm{C}=$ Sargassum sp., $\mathrm{D}=$ Kombinasi)

Figure 1. Average gonadal development stage of abalone $\boldsymbol{H}$. squamata on each treatment for 70 days culture period ( $A=$ Gracilaria sp., $B=$ Ulva sp., $C=$ Sargassum sp., $D=$ Combination)

terlihat, yaitu berturut-turut tertinggi diperoleh pada perlakuan pemberian pakan kombinasi (D), disusul perlakuan Ulva sp. (B) dan Gracilaria sp. (A) serta terendah pada perlakuan pemberian pakan Sargassum sp. (C), sedangkan yang lainnya masih berada pada TKG-1. Memasuki periode akhir pemeliharaan yaitu hari ke-70 sebagian induk abalon telah mengalami perkembangan gonad ke TKG-3 dan diperoleh hasil yang tertinggi pada perlakuan $D$, disusul perlakuan B dan A, sedangkan pada perlakuan $\mathrm{C}$ pada umumnya masih berada pada TKG-2. Hasil uji statistik yang dilakukan pada masing-masing perlakuan terhadap jumlah induk abalon yang TKG-3 sampai dengan pemeliharaan hari ke-70 menunjukkan adanya beda nyata antar perlakuan $(P<0,05)$. Hasil $u j i$ lanjut BNT menunjukkan bahwa perlakuan D berbeda nyata dengan perlakuan A dan B dan berbeda sangat nyata dengan perlakuan $C$.

Hasil yang diperoleh dalam penelitian ini secara umum menggambarkan bahwa untuk perkembangan gonad abalon $\mathrm{H}$. squamata dari TKG-1 ke TKG-3 memerlukan waktu minimum antara 28-42 hari pemeliharaan, kecuali pada perlakuan pemberian pakan Sargassum sp. yang relatif memerlukan waktu yang lebih lama. Hal ini diduga berhubungan erat dengan tingkat kesukaan abalon pada pakan yang diberikan (Chen, 1984) dalam hal ini pakan Gracilaria sp. dan Ulva sp. lebih disukai dari pada Sargassum sp. Namun, tingginya per- 
sentase induk abalon yang mengalami perkembangan gonad pada perlakuan kombinasi (Gracilaria sp. + Ulva sp. + Sargassum sp.) dibanding dengan perlakuan lainnya diduga disebabkan perpaduan nilai nutrisi dari ketiga jenis makroalga tersebut khususnya asam lemak yang dikandung satu sama lain saling melengkapi, sehingga terbukti lebih mendukung dalam memacu perkembangan gonad induk abalon $H$. squamata.

Pada umumnya pemberian pakan makroalga secara kombinasi menunjukkan rata-rata pertumbuhan yang lebih baik pada abalon dibandingkan dengan pemberian pakan makroalga secara tunggal (Fleming, 1995; Simpson \& Cook, 1998; Setyono, 2005). Selanjutnya Troell et al. (2006) menyatakan bahwa pakan makroalga jenis Ecklonia yang dikombinasikan dengan Gracilaria, Gellidium, Ulva ataupun Porphyra mampu mempercepat pematangan gonad induk abalon $\mathrm{H}$. midae. Perpaduan kandungan nutrisi yang terdapat dalam pakan makroalga yang dikombinasikan pada penelitian ini terlihat sangat mempengaruhi dalam memacu perkembangan gonad abalon $H$. squamata.

Hasil analisis proksimat dari masing-masing jenis makroalga yang digunakan dalam penelitian ini disajikan pada Tabel 1 .

Tabel 1 memperlihatkan bahwa kandungan protein dan lemak yang terdapat pada pakan Ulva sp. masing-masing sebesar $17,74 \%$ dan 2,73\%, lebih tinggi dibanding pakan Gracilaria sp. $(9,48 \%$ dan 1,52\%) maupun Sargassum sp. (7,29\% dan $1,99 \%)$.

Protein merupakan salah satu komponen yang sangat penting sebagai sumber asam amino untuk menopang pertumbuhan maupun perkembangan gonad abalon. Namun, kandungan protein pada pakan harus berimbang, mudah dicerna dan mengandung komposisi asam amino yang sesuai untuk abalon (BautistaTeruel et al., 1999). Sedangkan lemak selain berfungsi sebagai sumber energi, juga mengandung vitamin yang larut dalam lemak dan asam lemak esensial yang diduga sangat dibutuhkan untuk perkembangan gonad abalon. Hasil analisis asam lemak dari masingmasing jenis makroalga dan daging abalon yang digunakan dalam penelitian ini disajikan pada Tabel 2.

Uki \& Watanabe (1992) menyatakan bahwa lemak berperan penting sebagai sumber asam lemak esensial, khususnya HUFA (Highly Unsaturated Fatty Acid). Namun, hingga saat ini belum ada laporan yang menyebutkan mengenai kebutuhan asam lemak esensial bagi abalon. Tabel 2 memperlihatkan kandungan asam lemak daging abalon, khususnya asam lemak HUFA C20:5n3 dan C22:6n3 masing-masing sebesar $6,08 \%$ dan 1,31\%. Dari ketiga jenis makroalga yang digunakan dalam riset ini, ternyata hanya Sargassum sp. yang mengandung asam lemak HUFA, sedangkan baik pada Gracilaria sp. maupun Ulva sp. tidak terdapat kandungan asam lemak HUFA. Nampaknya, diduga kombinasi asam lemak dari ketiga jenis makroalga Gracilaria sp., Ulva sp., dan Sargassum sp. dalam penelitian ini saling melengkapi dan lebih sesuai dalam memacu tingkat kematangan gonad abalon $H$. squamata, dibanding dengan pemberian pakan makroalga secara tunggal yaitu Gracilaria sp. atau Ulva sp. maupun Sargassum sp. saja.

Hasil pengamatan terhadap pertumbuhan bobot badan abalon ( $H$. squamata) yang dilakukan pada masing-masing perlakuan selama 70 hari disajikan pada Gambar 2.

Berdasarkan hasil pengamatan menunjukkan bahwa pemberian pakan Sargassum sp. memberikan respons yang negatif terhadap pertumbuhan bobotnya (Gambar 2). Hal

Tabel 1. Komposisi proksimat dari masing-masing makroalga yang digunakan dalam penelitian (\% bobot kering)

Table 1. Proximate composition of each macroalgae used in the experiment (\% body weight)

\begin{tabular}{lccc}
\hline Parameter (\%) & Gracilaria & sp. & Ulva \\
sp. & Sargassum & sp. \\
\hline Protein (Protein) & 9.48 & 17.74 & 7.29 \\
Lemak (Fat) & 1.52 & 2.73 & 1.99 \\
Air (Moisture) & 2.14 & 3.36 & 2.55 \\
\hline
\end{tabular}


Tabel 2. Komposisi asam lemak (\% total lemak) dari masing-masing makroalga dan daging abalon (H. squamata)

Table 2. Fatty acid composition (\% total lipid) found in each kind of macroalgae and in abalone muscle (H. squamata)

\begin{tabular}{|c|c|c|c|c|}
\hline \multirow{2}{*}{$\begin{array}{l}\text { Asam lemak } \\
\text { Fatty acid }\end{array}$} & \multicolumn{4}{|c|}{$\begin{array}{l}\text { Jenis Sampel } \\
\text { Types of sample (\%) }\end{array}$} \\
\hline & Gracilaria sp. & Ulva sp. & Sargassum sp. & $\begin{array}{l}\text { Daging Abalon } \\
\text { Abalone muscle }\end{array}$ \\
\hline Lauric C12:0 & 2.63 & 0.17 & - & - \\
\hline Myristic C14:0 & 4.83 & 1.51 & 5.41 & 1.73 \\
\hline Myristoleic C14:1 & - & - & - & 0.93 \\
\hline Palmitic C16:0 & 0.75 & 2.19 & 5.70 & 18.22 \\
\hline Palmitoleic C1 6:1 & 43.64 & 35.78 & 35.74 & 0.53 \\
\hline Heptodecanoic $\mathrm{Cl}$ 7:0 & - & - & - & 1.65 \\
\hline Stearic $\mathrm{Cl} 8: 0$ & 6.63 & - & 0.45 & 8.41 \\
\hline Oleic Cl 8:1 & 9.63 & 31.40 & 11.62 & 5.44 \\
\hline Linoleic C18:2 & 2.68 & 5.54 & 2.61 & 10.71 \\
\hline Linolenic Cl 8:3 & 11.59 & 0.27 & 3.46 & 0.67 \\
\hline Arachidic C20:0 & - & - & - & 3.42 \\
\hline Eicosapentanoic C20:5n3 & - & - & 4.68 & 6.08 \\
\hline Docosapentanoic C22:6n3 & - & - & 1.23 & 1.31 \\
\hline
\end{tabular}

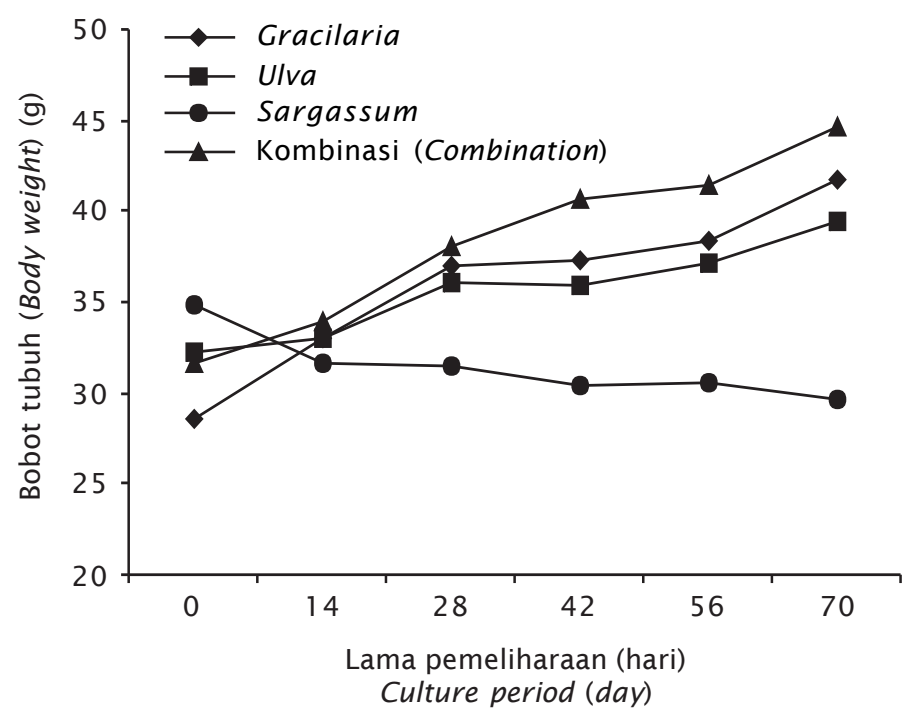

Gambar 2. Rata-rata bobot badan abalon (H. squamata) pada masing-masing perlakuan selama 70 hari pemeliharaan

Figure 2. The average weight growth of abalone $(\boldsymbol{H}$. squamata) on each treatment for 70 days culture period 
tersebut diduga abalon tidak banyak memanfaatkan Sargassum sp. sebagai pakan karena teksturnya yang agak keras dan susah untuk dicerna, jika dibanding dengan pakan Gracilaria sp. dan Ulva sp yang mempunyai tekstur relatif lebih lembut. Hal ini sesuai pendapat Chen (1984) yang menyatakan bahwa abalon lebih menyukai pakan alga yang bertekstur lembut.

Hasil pengukuran pertumbuhan bobot mutlak dan laju pertumbuhan harian bobot abalon yang dilakukan pada masing-masing perlakuan selama 70 hari pemeliharaan menunjukkan adanya beda nyata antar perlakuan $(P<0,05)$. Hasil uji lanjut BNT menunjukkan bahwa antara perlakuan pemberian pakan Gracilaria sp., Ulva sp., maupun pakan kombinasi tidak berbeda nyata, namun berbeda nyata terhadap pemberian pakan Sargassum sp. Induk abalon yang diberi pakan kombinasi menghasilkan pertumbuhan bobot mutlak dan laju pertumbuhan harian bobot masing-masing sebesar 13,17 $\pm 2,92 \mathrm{~g}$ dan $219,56 \pm 48,82 \mu \mathrm{g} /$ hari, disusul pakan Gracilaria sp. sebesar 13,03 $\pm 1,50$ dan $217,17 \pm 25,06 \mu \mathrm{g} /$ hari, pakan Ulva sp. sebesar $7,26 \pm 4,28 \mathrm{~g}$ dan $121,06 \pm 170,52 \mu \mathrm{g} /$ hari dan yang terendah adalah pakan Sargassum sp. yaitu masing-masing sebesar $-5,19 \pm 6,16 \mathrm{~g}$ dan $-86,44 \pm 102,68 \mu \mathrm{g} /$ hari (Tabel 3). Hal ini diduga karena tekstur dari Gracilaria sp. dan Ulva sp. terlihat lebih lunak dibanding Sargassum sp. yang memiliki tekstur lebih keras dan kaku, sehingga abalon memerlukan energi yang lebih sedikit untuk mengkonsumsi kedua jenis makroalga tersebut dibanding Sargassum sp. $\mathrm{Hal}$ ini diduga menyebabkan terjadinya perbedaan retensi energi pada tubuh abalon yang direfleksikan melalui perbedaan pertumbuhan.

Dari hasil penelitian ini menunjukkan bahwa pemberian pakan Gracilaria sp. yang dilakukan secara tunggal lebih cenderung untuk memacu pertumbuhan cangkang abalon, dibanding dengan pemberian pakan kombinasi Gracilaria sp. + Ulva sp. + Sargassum sp. yang memberikan respons pertumbuhan cangkang yang lebih rendah. Hal ini disebabkan karena pada perlakuan pemberian pakan kombinasi Gracilaria sp. + Ulva sp. + Sargassum sp., energi yang diperoleh dari makanan selain diperuntukkan bagi pertumbuhan, sebagian besar digunakan bagi perkembangan gonadnya. Menurut Naidoo et al. dalam Troell et al. (2006), bahwa pemberian pakan makroalga secara kombinasi antara Ecklonia maxima dengan Gracilaria sp. ataupun Ulva sp. dapat memacu tingkat pertumbuhan abalon $H$. midae.

Hasil pengamatan terhadap rata-rata pertumbuhan bobot mutlak dan laju pertumbuhan harian, pertumbuhan panjang

Tabel 3. Rata-rata pertumbuhan bobot mutlak, laju pertumbuhan harian, pertumbuhan mutlak panjang dan lebar cangkang, serta rata-rata sintasan abalon (H. squamata) pada masingmasing perlakuan selama 70 hari pemeliharaan

Table 3. The average of absolute weight growth, daily growth rate, absolute shell length and width growth and survival rate of abalone (H. squamata) on each treatment for 70 days culture period

\begin{tabular}{|c|c|c|c|c|}
\hline \multirow{2}{*}{$\begin{array}{l}\text { Parameter } \\
\text { Parameter }\end{array}$} & \multicolumn{4}{|c|}{$\begin{array}{l}\text { Perlakuan } \\
\text { Treatment }\end{array}$} \\
\hline & Gracillaria sp. & Ulva sp. & Sargassum sp. & $\begin{array}{l}\text { Kombinasi } \\
\text { Combination }\end{array}$ \\
\hline $\begin{array}{l}\text { Pertumbuhan bobot mutlak } \\
\text { Absolute weight growth (g) }\end{array}$ & $13.17 \pm 2.92^{b}$ & $7.26 \pm 4.28^{b}$ & $-5.19 \pm 6.16^{a}$ & $13.03 \pm 150^{b}$ \\
\hline $\begin{array}{l}\text { Laju pertumbuhan harian }(\mu \mathrm{g} / \mathrm{hari}) \\
\text { Daily growth rate }(\mu \mathrm{g} / \text { day })\end{array}$ & $219.56 \pm 48.82^{b}$ & $12106 \pm 70.52^{b}$ & $-86.44 \pm 102.68^{a}$ & $217.1 \pm \pm 25.06^{b}$ \\
\hline $\begin{array}{l}\text { Pertumbuhan mutlak panjang cangkang } \\
\text { Absolute shell length growth (mm) }\end{array}$ & $6.40 \pm 0.44^{b}$ & $5.15 \pm 4.47^{b}$ & $0.63 \pm 0.70^{a}$ & $5.19 \pm 0.21$ \\
\hline $\begin{array}{l}\text { Pertumbuhan mutlak lebar cangkang } \\
\text { Absolute shell width growth (mm) }\end{array}$ & $3.68 \pm 0.74^{b}$ & $3.20 \pm 3.48^{b}$ & $0.46 \pm 0.33^{\mathrm{a}}$ & $3.87 \pm 0.65^{b}$ \\
\hline $\begin{array}{l}\text { Sintasan } \\
\text { Survival rate (\%) }\end{array}$ & $66.7+15.3^{\mathrm{a}}$ & $56.7 \pm 115^{a}$ & $56.7 \pm 5.8^{a}$ & $73.3+15.3^{\mathrm{a}}$ \\
\hline
\end{tabular}


Tabel 4. Kisaran kualitas air selama pemeliharaan induk abalon H. squamata

Table 4. Range of water quality parameters during the culture of abalone $\boldsymbol{H}$. squamata broodstock

\begin{tabular}{lc}
\hline \multicolumn{1}{c}{$\begin{array}{c}\text { Parameter } \\
\text { Paramet er }\end{array}$} & $\begin{array}{c}\text { Kisaran } \\
\text { Range }\end{array}$ \\
\hline Suhu (Temperature) $\left({ }^{\circ} \mathrm{C}\right)$ & $27.8-28.9$ \\
Salinitas (Salinity) $(\mathrm{ppt})$ & $34-35$ \\
Oksigen terlarut (Dissolved oxygen) $(\mathrm{mg} / \mathrm{L})$ & $4.3-5.7$ \\
$\mathrm{pH}$ & $8.0-8.4$ \\
$\mathrm{NO}_{2}(\mathrm{mg} / \mathrm{L})$ & $0.004-0.036$ \\
$\mathrm{NH}_{3}(\mathrm{mg} / \mathrm{L})$ & $0.002-0.059$ \\
\hline
\end{tabular}

mutlak dan lebar mutlak cangkang dan sintasan abalon ( $H$. squamata) yang dilakukan pada masing-masing perlakuan selama 70 hari pemeliharaan tersaji pada Tabel 3.

Berdasarkan Tabel 3 terlihat bahwa jenis pakan yang diberikan menghasilkan sintasan induk abalon $\mathrm{H}$. squamata yang tidak berbeda nyata $(P>0,05)$. Hal ini menunjukkan bahwa kandungan nutrisi pada jenis pakan yang diterapkan dalam penelitian ini memberikan respons yang relatif sama dalam menopang sintasan induk abalon $H$. squamata. Hasil pengamatan di lapangan menunjukkan bahwa tingginya tingkat kematian induk abalon lebih banyak disebabkan karena adanya serangan bakteri selama percobaan ini berlangsung. Johnny (2007) melaporkan bahwa bakteri yang menyerang induk abalon pada umumnya berasal dari jenis Vibrio spp. dan Flexibacter.

Kualitas air media pemeliharaan yang terdiri atas peubah fisika dan kimia berperan penting dalam menentukan tingkat kelayakan habitat sebagai penopang bagi kehidupan dan perkembangan induk abalon selama pemeliharaan. Hasil pengamatan kualitas air selama pemeliharaan meliputi suhu, salinitas, $\mathrm{DO}, \mathrm{pH}$, $\mathrm{NO}_{2}, \mathrm{NH}_{3}$ tersaji pada Tabel 4. Terlihat bahwa kisaran nilai-nilai kualitas air tersebut masih berada dalam rentang yang layak untuk mendukung kehidupan induk abalon $H$. squamata.

\section{KESIMPULAN}

1. Pemberian pakan makroalga memberikan pengaruh terhadap tingkat perkembangan gonad dan laju pertumbuhan bobot harian induk abalon $H$. squamata.
2. Pakan makroalga kombinasi Gracilaria sp. + Ulva sp. + Sargassum sp. (rasio $1: 1: 1$ ) memberikan hasil yang lebih baik dalam memacu tingkat kematangan gonad induk abalon H. squamata.

\section{UCAPAN TERIMA KASIH}

Kepada staf teknisi abalon Sdr. Made Buda, Wiwin Adiwinata, dan Hendra Agung Kurniawan yang telah banyak membantu selama persiapan sampai pada pelaksanaan riset ini dan juga kepada Departemen Pendidikan Nasional yang telah mendanai penelitian ini.

\section{DAFTAR ACUAN}

Bautista-Teruel, Myrna N. Oseni, \& Millamena, M. 1999. Diet development and evaluation for juvenile abalone, Haliotis asinina: protein energy levels. Aquaculture, 178: 117-126.

Chen, H.C. 1984. Recent inovation in cultivation of adible molluscs in Taiwan, with special reference to the small abalone Haliotis diversicolor and the hard clam Meretrix lusoria. Aquaculture, 39: 11-29.

Cox, K.W. 1996. California Abalones. Famili Haliotidae. California Fish and Game. Fisheries Bulletin, $118 \mathrm{pp}$.

Effendie, M.I. 1997. Metode Biologi Perikanan. Yayasan Dewi Sri, Bogor, $105 \mathrm{hlm}$.

Fleming, A. E.1995. Growth, intake, feed conversion efficiency and chemosensory preference of the Australian abalone Haliotis rubra. Aquaculture, 132: 297-310.

Gordon, H.R. \& Cook, P.A. 2001. World abalone supply, markets and pricing: historical, current and future. J. Shellfish Res., 20: 567570. 
Gordon, H.R. \& Cook, P.A. 2004. World abalone fisheries and aquaculture update: supply and market dynamics. J. Shellfish Res., 23: 935-939.

Hahn, K.O. 1989. Artificial induction of spawning and fertilization. In: Handbook of culture of abalone and other marine gastropods (Hahn, K.O. ed.). CRC Press, Inc. Boca Raton, Florida. p. 53-70.

Indarjo, A., Hartati, R., Samidjan, I., \& Anwar, S. 2007. Pengaruh pakan Gracilaria sp. dan Pakan Buatan terhadap pertumbuhan Abalon Haliotis asinina. Prosiding Seminar Nasional Moluska Dalam Penelitian, Konservasi dan Ekonomi, hlm. 215-228.

Johnny, F. 2007. Kasus infeksi bakteri Vibrio sp. pada induk abalone Haliotis discus discus. Prosiding Seminar Nasional Moluska Dalam Penelitian, Konservasi dan Ekonomi, hlm. 273-281.

Moss, G.A. 1998. Yellowfoot paua a candidate for farming. Seafood New Zealand, June 1998, p. 28-30.

McBride, S. \& Conte, F.S. 2008. California abalone aquaculture. Diakses dari http:// aqua.ucdavis.edudbweboutreachaquaASAQA10.PDF. Pada tanggal 28 Mei 2008.

Padua, M., Fontoura, P.S.G., \& Mathias, A.L. 2004. Chemical composition of Ulvaria oxysperma (KStzing) Bliding, Ulva lactuta (Linnaeus) and Ulva fascita (Delile). J. of Brazilian Archives of Biology and Technology, 47(1): 49-55.

Priyambodo, B., Sofyan, Y., \& Jaya, I.S. 2005. Produksi Benih Kerang Abalone (Haliotis asinina) Di Loka Budidaya Laut Lombok. Seminar Nasional Tahunan Hasil Penelitian Perikanan dan Kelautan. Perikanan dan Kelautan UGM, Yogyakarta, hlm. 144-148.

Rusdi, I., Susanto, B., \& Rahmawati, R. 2008. Studi penerapan berbagai jenis pakan alga terhadap perkembangan gonad abalon Haliotis squamata. Prosiding Bidang Budidaya Perairan, Seminar Nasional Perikanan dan Kelautan, Unbraw, Malang, hlm. 75-80.

Sales, J. \& Britz, P.J. 2001. Review: research on abalone (Haliotis midae $\mathrm{L}$ ) cultivation in South Africa. Aquaculture Research, 32: 863-874.
Setyono, D.E.D. 2005. Abalone (Haliotis asinina L.): 5 . Juvenile rearing and on growing culture. Oseana, XXX(2): 1-10.

Setyono, D.E.D. 2006. Induction Spawning for the tropical abalone (Haliotis asinina) in the laboratory. Indonesian Aquaculture J., 1(1): 17-27.

Simpson. J.A \& Cook, P.A. 1998. Rotation diets: a method of improving growth of cultured abalone using natural algal diets. J. Shellfish. Res., 17: 635-640.

Singhagraiwan, T. \& Doi, M. 1993. Seed production and culture of a tropical abalone Haliotis asinina Linne. Department of fisheries, Ministry of Agriculture and Cooperatives. Thai. Mar. Fish. Res. Bull., 2: 83-94.

Shepherd, S.A. \& Steinberg, P.D. 1992. Food preference of three Australian abalone species with review of algal food of abalone. In: Abalone of the world: biology, fisheries and culture. Shepherd, S.A, Tegner, M.J., \& Guzman Del Proo, S.A. (Eds.). Proceedings of the $1^{\text {st }}$ International Symposium on Abalone. Fishing News Books, p. 169-181.

Steel, R.G.D. \& Torrie, J.H. 1993. Prinsip dan Prosedur Statistika. PT Gramedia Pustaka Utama, Jakarta, $748 \mathrm{hlm}$.

Susanto, B., Hanafi, A., Zafran, \& Ismi, S. 2007. Pematangan gonad induk dan perbaikan kualitas benih abalon (Haliotis squamata). Laporan Teknis BBRPBL-Gondol, Bali, 17 hlm.

Troell, M., Robertson-Andersson, D., Anderson, R.J., Bolton, J.J., Maneveldt, G., Halling, C., \& Probyn, T. 2006. Abalone farming in South Africa: An overview with perspectives on kelp resources, abalone feed, potential for on-farm seaweed production and socioeconomic importance. Aquaculture, 257: 266-281.

Uki, N. \& Watanabe, T. 1992. Review of nutritional requirement of abalone Haliotis spp and development of more efficient diets. In: Abalone of the world: biology, fisheries and culture. Shepherd, S.A, Tegner, M.J., \& Guzman Del Proo, S.A. (Eds.). Proceedings of the $1^{\text {st }}$ International Symposium on Abalone. Fishing News Books, p. 504-517.

Zonneveld, N., Huisman, E.A., \& Boon, J.H. 1991. Prinsip-prinsip Budidaya Ikan. Penerjemah Pustaka Utama, Gramedia, Jakarta, 71 hlm. 